except those due to viruses. Our situation would have in fact deteriorated instead of improved. The sulphonamides preceded penicillin by some years, and had transformed the outlook in many acute infections. But bacteria, including gonococci, haemolytic strejptococci, and pneumococci, were already becoming resistant to them. Penicillin saved the day: without it there might by now have been no effective chemotherapy at all. We now know from bitter experience with antibiotics that, in dealing with some bacteria, to have only one antibacterial drug is hopeless. When resistance develops, another must take its place, at least for a time.

This is not the place for a catalogue of the successes of antibiotic therapy. Older members of the profession know well what they have achieved. Those who do not remember the days when every case of bacterial endocarditis was fatal cannot have the same understanding. How many millions of people are still living who owe their survival to antibiotics is beyond computation. It may not be out of place to refer to a much smaller class of individuals who owe not their lives but the quality of those lives to the discovery made at Oxford in 1940. These are people who have been inclined and able to make a special study of antibiotics in the laboratory and the ward. To them it has simply meant that life ever since has been far more exciting and worth while. They have been able to render services to the clinician and to the patient which were undreamed of until then, and at the same time to explore a wonderful new field in microbiology. The gratitude of such workers to Florey knows no bounds, and those who also had the privilege of his friendship valued it above any other. They would all join in saluting the passing of a great man.

1 Florey, Sir H. W., Brit. med. J., 1945, 2, 635.

\section{Steroid Treatment in the Nephrotic Syndrome in Childhood}

A high proportion of children with the idiopathic nephrotic syndrome respond to intensive treatment with steroids, which leads to disappearance of proteinuria, loss of oedema, and correction of the biochemical abnormalities in the blood. This good response is rarely seen in adult patients. G. C. Arneil and C. N. Lam ${ }^{1}$ showed that 55 out of 80 nephrotic children were in remission and free of proteinuria within four weeks of starting steroid therapy. This improvement is most likely to be seen in those patients found to have only minimal abnormalities in their kidneys as seen at biopsy ${ }^{2-5}$ and in whom the proteinuria is highly selective ${ }^{6}{ }^{7}$-only certain proteins appearing in the urine. Though no controlled trial has been reported in children, marked improvement in prognosis is also usual as a result of intensive steroid therapy. ${ }^{8-10}$ Surveys with a five-year follow-up show that the death rate has been reduced to $10-15 \%$ and the proportion of children free from significant proteinuria amounts to $65-70 \% .^{\prime \prime \prime}$ Indeed, the results of treatment with steroids in children are so impressive that the opportunity for a controlled trial has been lost. ${ }^{12}$

Since the introduction of prednisolone three regimens of treatment with steroids for the nephrotic syndrome have been developed, and each has its advocates. Prednisone or prednisolone may be given daily for at least six weeks in high dosage-intensive therapy ${ }^{13}$; or the drug may be given as long-term treatment, either on three consecutive days out of each week-intermittent therapy ${ }^{14}$-or on alternate days. It is well-recognized that premature cessation of treatment with steroids is likely to lead to early relapse. Unfortunately, what is not clear is whether or not some children are more likely to relapse than others, nor is there any means of identifying those likely to relapse. $\mathrm{K}$. Lange ${ }^{15}$ suggested that all children should receive intermittent therapy for at least one year. Arneil and Lam disagreed. They showed that when children were treated intensively with steroids for at least 40 days and the treatment then stopped $40 \%$ did not relapse. Arneil and Lam have suggested that long-term treatment should be reserved for those children who relapse after the end of an initial course of intensive treatment.

Though intermirtent therapy has fewer side-effects than a continuous regimen it is sometimes unsuccessful in preventing relapse, and furthermore it is apt to cause suppression of growth and of adrenal function. ${ }^{16} 17$ The alternate-day regimen was reported by L. F. Soyka and K. M. Saxena, ${ }^{18}$ who treated nine children and achieved good control of the nephrotic syndrome. Growth was not suppressed when this regimen was used from the start; and children who had been on intermittent therapy and were changed to the alternate-day regimen began to grow again. D. S. Fleisher ${ }^{19}$ showed that adrenal suppression also seems to be less with alternate-day therapy than with continuous therapy. Balance studies are positive for both nitrogen and calcium in nephrotic children receiving either intermittent or alternate-day therapy. ${ }^{20}$ However, alternate-day therapy has been used less than intermittent therapy, and its effectiveness has still to be substantiated by other workers and by long-term follow-up.

Arneil, G. C., and Lam, C. N., Lancet, 1966, 2, 819.

Blainey. J. D., Brewer, D. B., Hardwicke, J., and Soothill, J. F.,

verner, R. L.. Worthen, H. G., and Good, R. A., F. Pediat., 1961, 58, 620 .

- Black, J. A., and White, R. H R., in Recent Advances in Paediatrics, ed. Gairdner, D., 3rd ed., London, 1965, p. 307

Drummond, K. N., Michael, A. F., Good, R. A., and Vernier, R. L., 7. clin. Invest., 1906, 45, 620.

- Cameron, J. S., and White, R. H. R., Lancet, 1965, 1, 463.

C.mm ron, J. S., and Blandford, G.. Lancet, 1966, 2, 242.

Riley, C. M., and Scaglione, P. R., Pediatrics, 1959, 23, 561.

Brown, R. B., Burke, E C., and Stickler. G. B., Mayo Clin. Proc., $1965,40,384$.

10 Saxena, K. M., and Crawford. J. D., New Engl. 9. Med., 1965, 272, 522.

1 Cornfeld, D., and Schwarrz, M. W., 7. Pediat., 1966, 68, 507.

12 Barnett, H. L., Arch. Dis. Chzldh., 1966, 41, 229.

13 Arneil, G. C., Lancet, 1956, 1, 409.

14 Lange, K., Slobody, L., and Strang, R., Pediatrics, 1955, 15, 156.

Lange, $\mathrm{K}_{\text {., }}$ in Proceedings of the Third International Congress of Chemotherapy, Stuttgart, 1964, p. 1623.

16 Fleisher, D. S., McCory, W. W., and Rapoport, M., F. Pediat., 1960,

17 Siegel, S. C., Lovin, B. J., Ely, R. S., and Kelly, V. C., Pediatrics, $1959,24,434$.

18 Soyka, L. F., and Saxena, K. M. 7. Amer, med. Ass., 1965, 192, 225.

10 Fleishet, D. S., F. Pediat., 1967, 70, 54

so Johnston, J. A., Manson, G. Meyer, R., Whitten, C., and Guillemette, M. E., Amer. ๆ. Dis. Child., 1967, 114, 288

Friedman, M., and Strang, L. B., Lancet, 1966, 2, 568.

"2. Friedman, M., and Strang, L. B., Lance

23 Gotoff. S. P., Fellers, F X., Vawter, G. F., Janeway, C. A., and Rosen,

2. West, C. Dew E., Hongl. R., and Holland. N. H., 7. Pediat., 1966, 68, 516. White, R. H. R., Cameron. J. S., and Trounce, J. R., Brit. med. 7., 1966, 2, 853.

${ }^{26}$ Grupe, W. E.: and Heymann, W., Amer. F. Dis. Child., 1966, $112,448$. ana Berton, W. M., f. Pediat., 1957, 70, 758. 
M. Friedman and L. B. Strang ${ }^{21}$ suggested that treatment with intramuscular corticotrophin would avoid the effect of steroids in suppressing the growth of asthmatic and nephrotic children, and they showed an impressive promotion of growth in children treated with corticotrophin. On the other hand, long-term intramuscular therapy is not welcomed by children. On balance it seems that oral corticosteroids are still the drugs of choice both for the initial treatment and for the infrequent relapses. Review of the literature suggests that the safest steroids are prednisolone and prednisone.

A small number of children with the nephrotic syndrome do not respond to steroids from the beginning. These children not infrequently have haematuria. ${ }^{22}$ In renal biopsies proliferative or membranous changes may be seen on light microscopy $^{3}$ and immunoglobulin deposits can be shown by fluorescent microscopy. ${ }^{5}$ Differential protein clearance may show unselective proteinuria, ${ }^{7}$ and the serum levels of beta1-C globulin may be reduced. ${ }^{23}$ A patient with these findings is very unlikely to benefit from prolonged treatment with steroids. Recently a number of centres have published encouraging results from the use of immunosuppressive drugs in relatively small series of steroid-resistant cases. ${ }^{24-27}$ These claims remain to be substantiated, and the results of two multi-centre trials recently started will be awaited with great interest. If these immunosuppressive drugs are proved to be effective they may also have a place in treating the patients who suffer frequent relapses, who at present so often also suffer from the side-effects of steroid therapy.

\section{Notifications of Abortions}

Patients will entrust their doctor with the secrets of their mental and bodily ills in intimate detail only if they know that the whole relationship is completely confidential. To doctors the relationship with each individual patient has been from time immemorial a sacred trust, nothing less. Only in this way can the patient's interests be fully served, whether they concern the more trivial consequences of ill-health or matters of life and death.

Now it appears from press reports that the Government wishes to make provision under the Abortion Act, 1967, for police officers to have access to records in cases of therapeutic abortion. The reason is said to be that such powers are needed to stop abuses-in the third reading of the Bill in its passage through Parliament the Minister of Health said, "It is essential that with due precautions there should be access to the records." The medical profession has always made plain its view that any departure from traditional practice must be harmful to patients, so that the B.M.A. Special Committee, in its report on therapeutic abortion, ${ }^{2}$ was doing no more than stress a time-honoured precept in stating that "All notification should be confidential and made by one medical practitioner to another." The same rule governs the notification of cases of infectious diseases, as it will the notification of drug addicts. And up to a point the Government has conceded the validity of this view, for the Abortion Act requires doctors to notify their cases only to the Chief Medical Officers of the Ministry of Health and the Scottish Home and Health Department. Representatives of the medical profession are discussing the matter with officials of the Ministry of Health and Home Office (see Supplement, page 54).

\footnotetext{
1 Hansard, 13 July 1967, col. 1252.
}

2 Brit. med. Y., 1966, 2, 40.
That a breach of the confidential relationship between doctor and patient is permissible in rare and exceptional circumstances is acknowledged. Under a court order, for instance, a doctor may be compelled to give evidence. Doctors acquiesce in this despite their repugnance for it because it is never lightly and always publicly invoked. It $\stackrel{\mathbb{Q}}{\mathbb{Q}}$ serves to protect the rights of other individuals, and is subject $c$ to legal scrutiny to ensure that it serves that end. Even so, $\overrightarrow{\vec{A}}$ medical men have had occasion to protest vigorously in the $\frac{\sigma}{+}$ witness-box against the forced disclosure of their patient's $\frac{C}{5}$ interests and confidences. But the proposal now seems to be that information about individual patients, notified to the $\mathbb{\nabla}$ Chief Medical Officers, is to be open to the scrutiny of the police without any public testing of the need for it, indeed without any public knowledge that in a particular case it is being done at all.

Obviously where State security or serious crime is concerned the police must have powers to investigate suspicious circumstances, and criminal abortion must be counted serious. But it is alarming to think that the Government can contem- if plate using an Act regulating therapeutic abortion to take $\mathscr{G}$ special powers for police action when that action is to be based on information supplied by one doctor to another.

\section{Surgical Treatment of Intracranial Tumours}

In every field of medicine there is a plea for earlier diagnosis, but this demand can be justified only by improvement in the results of treatment. The time taken to assess the effects of advances in treatment depends on the life expectation with the condition under investigation. Recently J. N \& Segelov and his colleagues ${ }^{1}$ have reported the results of a $\overrightarrow{\vec{P}}$ survey of 700 cases of intracranial tumour opera: $d$ on in Australia between 1930 and 1960. This has shown an encouraging improvement in the results of surgery for extracerebral tumours but no substantial change in the outlook for most of those within the brain.

The greatest change in the results of treatment is in the group of pituitary adenomas, in which the operative mortality is considerably lower and the degree of restoration of vision is improved. This is due largely to the advent of corticosteroid therapy and advances in radiotherapy, which $\bigcirc$ may have also reduced the need for operation in some patients. N Nevertheless, the ultimate result depends almost entirely on the size and situation of the neoplasm. Very large tumours still carry a high mortality, and few patients survive ten $N$ years, but if a smaller tumour is treated early the operative ${ }_{\omega}^{N}$ and later mortalities are low and permanent recovery of vision is to be expected. Unfortunately recognition of these 0 neoplasms is still frequently delayed until they are extensive. The rare invasive adenomas are still unresponsive to treatment as a rule.

Some craniopharyngiomas can now be totally removed, especially if the lesion is cystic. It is still too soon to be dogmatic about the late results of these operations, but there is no reason to suspect they will not be excellent.

Meningiomas show a much reduced operative mortality, morbidity, and recurrence rate. The outcome again depends on the size and situation of the tumour, but about $70 \%$ of patients may be expected to live ten years or more, with a

\footnotetext{
Segelov, J. N., Vanderfield. G. K., Gye. R. S., and Morson, S. M..
Med. ๆ. Aust., 1967. 2, 48.
} 